\title{
Feasibility analysis of dryer with rice husk energy for drying jackfruit Dodol in Lombok
}

\author{
Ida Bagus Alit and I Gede Bawa Susana * \\ Department of Mechanical Engineering, Faculty of Engineering, University of Mataram, Jl. Majapahit No. 62 Mataram- \\ Nusa Tenggara Barat 83125, Indonesia
}

Global Journal of Engineering and Technology Advances, 2021, 06(03), 075-080

Publication history: Received on 08 February 2021; revised on 10 March 2021; accepted on 12 March 2021

Article DOI: https://doi.org/10.30574/gjeta.2021.6.3.0044

\begin{abstract}
Sun drying is popularly used in Lombok to dry food items including jackfruit Dodol because it is easy and cheap. This type of drying has a weakness, which is very weather dependent. When it is cloudy or rainy, the drying process will stop, which will affect the income level of the jackfruit Dodol business. To overcome this, it is done through the application of a dryer with rice husk energy. Rice husks can be an alternative energy in drying process because they are easy to obtain and cheap. To make rice husks as drying energy, it can be done through an energy conversion process using a heat exchanger that is placed in a furnace. Tests were carried out in the drying process to produce a dry product of $5 \mathrm{~kg}$ of jackfruit Dodol. The drying temperature is obtained from the result of the energy conversion process between burning rice husks in a furnace with environmental air flowing in the heat exchanger pipe. The resulting hot air flows into the drying chamber. This makes the product more hygienic and drying process can be all the time. The implication of the application of the rice husk energy dryer is to increase the jackfruit Dodol business income. This dryer provides a return on investment (ROI) rate of $304.48 \%$ with the break-even point (BEP) occurring at 0.2778 years or 3.3336 months. This means $\mathrm{k}<\mathrm{n}(0.2778$ years $<7$ years $)$, so it can be stated that the investment in rice husk energy dryer for drying jackfruit Dodol is feasible.
\end{abstract}

Keywords: Drying; Rice Husk; Jackfruit Dodol; Break-even Point

\section{Introduction}

Jackfruit Dodol is a traditional cake made from fresh and ripe jackfruit. This cake is in great demand by visitors who come to Lombok and are used as souvenirs. This is related to Lombok as a tourist destination. The high demand for jackfruit lunkhead has an impact on the increasing number of small household businesses to produce this cake. Jackfruit Dodol so that it can last a long time, preservation is carried out. Preservation is cheap and easy to do by home industries, namely through drying.

Drying is usually done by drying it in the sun. This is an inexpensive way because it does not cost energy consumption. Of course, sun drying can only be done when the weather is sunny. The weakness of sun drying is when the weather is cloudy or rainy, so the drying process will stop. This has an effect on decreasing the quality of the products produced. To overcome these weaknesses, a tool that is easy to operate and affordable price is designed. A tool suitable for household industries of jackfruit Dodol in Lombok is a dryer with rice husk biomass energy. Rice husk is one of biomass that is easily available in Lombok and cheap. Rice husk as a byproduct of paddy which reaches $20 \%$. Rice husks are waste from rice production, where rice is the staple food of the people of Lombok. Lombok Island has the potential for rice husks of 269,420.20 tons, while for West Nusa Tenggara it is 533,150.80 tons. This potential is predicted to produce

\footnotetext{
${ }^{*}$ Corresponding author: I Gede Bawa Susana

Department of Mechanical Engineering, Faculty of Engineering, University of Mataram, Jl. Majapahit No. 62 Mataram-Nusa Tenggara Barat 83125, Indonesia.
} 
energy capable of supplying a power capacity of 60-65 MW [1,2]. Rice husks are effectively used as an alternative as waste energy. Rice husks provide an even and stable burning effect as a result of the high cellulose composition. The composition of cellulose is 50\%, besides that it also contains lignin (25\% -30\%), bulk density $90-150 \mathrm{~kg} / \mathrm{m} 3$, moisture $(10 \%-15 \%)$, and silica $(15 \%-20 \%)[3,4]$. The heating value of rice husk is quite high, namely $12.3 \mathrm{MJ} / \mathrm{kg}$, this value is equivalent to half the calorific value of coal [5]. The use of rice husks for drying can be done through a thermal energy conversion process. This can be done by using a heat exchanger. Research related to the use of heat exchangers and biomass has been widely carried out in the postharvest drying process. To maintain the quality of food during storage, post-harvest handling is an important stage [6]. Rice husks as fuel produce high combustion efficiency reaching 99.2\%, fire stabilization, low emissions in tests carried out using a rectangular fluidized bed combustor [7]. Testing rice husks as an energy source for the dryer resulted in an average drying temperature in the no-load drying room of $71.10^{\circ} \mathrm{C}[8]$ and $72.79^{\circ} \mathrm{C}$ with the highest temperature of $109.2^{\circ} \mathrm{C}$ [9]. The test results using a stove for burning $1 \mathrm{~kg}$ of rice husk showed that after 30 minutes complete combustion occurred with a maximum temperature reaching $556.5^{\circ} \mathrm{C}[10]$. The use of rice husks through an energy conversion process in which the drying process of food is carried out in the drying room gives a more hygienic product result. Drying is not time-bound and can take place during cloudy or rainy weather.

The dryer uses a drying chamber and a furnace with the addition of a heat exchanger. The use of this heat exchanger is intended so that the dried product is not contaminated with husk smoke. A heat exchanger is added in the furnace to facilitate the conversion of biomass into thermal energy. To implement heat transfer between two fluids that have different temperatures and are separated by a wall using a heat exchanger [11]. The use of dryers also has a good impact on workers. This can be seen from research [12] that the drying process of fish which is carried out in a drying chamber designed based on worker anthropometric data reduces the rate of musculoskeletal complaints by $26.70 \%$. Increasing properties and logistics factors are needed in the utilization of rice husks as a renewable energy source [13]. The dryer is designed to increase the effectiveness of rice husks as fuel in the Dodol drying process. Dodol artisan and farmers will get added value from the use of rice husks as a source of drying energy. This added value is calculated based on the level of benefit obtained by the Dodol artisan after using the rice husk dryer.

The level of benefit is analyzed to describe the condition of the jackfruit Dodol artisan in the short and long term. This is done based on the payback period (PBP), break-even point (BEP), and Return on Investment (ROI) method of the use of rice husk energy dryer. BEP is a condition of a company that does not suffer losses and does not gain profits [14]. ROI is the company's ability to generate profits that will be used to cover the investment issued.

\section{Material and methods}

The research used raw materials in the form of $6 \mathrm{~kg}$ of jackfruit and $2 \mathrm{~kg}$ of sugar for the manufacture of Dodol. The energy source uses rice husks. The drying process using a dryer consisting of a furnace, heat exchanger, and drying chamber was adopted from the study [9]. Furnace materials and heat exchangers are easily available on the market at affordable prices. The study was conducted to analyze the level of benefit from the application of the rice husk dryer used to dry jackfruit Dodol. The analysis was carried out on data on workers' income and the benefits of investment costs for the household scale.

Payback period (PBP) analysis aims to determine the length of time the investment can be returned when a break-even point (BEP) occurs. The PBP calculation uses a comparison of the investment cost of the rice husk energy dryer (stove with heat exchanger pipes, drying room, and traditional mixer) with a profit outside of investment. Profits are income minus operating costs. The operational costs in the form of raw materials include jackfruit, sugar, and wages for workers. Payback period is calculated based on Equation 1 [15].

$\mathrm{k}_{(\mathrm{PBP})}=\frac{\text { Investment }}{\text { Annual Benefit }}($ year)

$\mathrm{k}_{\text {(PBP) }}$ is the number of payback periods; annual benefit (IDR/year) is income minus operating expenses. Certain criteria are needed to determine whether an investment plan is economically feasible or not. The investment plan is feasible if it meets the requirements, namely $\mathrm{k} \leq \mathrm{n}$ and $\mathrm{n}$ is the investment age.

The volume of Dodol jackfruit production when the artisan does not suffer losses and does not get profit is calculated using BEP. This is based on the use of the rice husk energy dryer. Based on [16], for the breakeven analysis it is assumed that total revenue is obtained from the sale of all products produced. The comparison of total revenue from sales of production at PBP with the selling price per kg of jackfruit Dodol is referred to as BEP. 


$$
\mathrm{BEP}=\frac{\mathrm{FC}}{\mathrm{p}-\mathrm{VC}}
$$

FC is a fixed fee; $\mathrm{p}$ is the selling price per unit of product; VC is the variable cost to make $\mathrm{X}$ the product.

$\mathrm{pX}=\mathrm{TR}$

$\mathrm{TR}=\mathrm{TC}$

TR is the total revenue from the sale of X products. $\mathrm{X}$ is the volume of production that causes the company to break-even point (BEP). Profits are obtained if the production is above X (exceeding the break-even point). TC is the total cost of making X products. The break-even point will be obtained when the total revenue is exactly the same as the total costs involved.

The calculation of return on investment (ROI) uses the proceeds from the sale of jackfruit Dodol when PBP is reduced by investment compared to investment. Investment in the form of rice husk energy dryer.

$$
\text { ROI }=\frac{\text { Total Sales-Investment }}{\text { Investment }} \times 100 \%
$$

\section{Results and discussion}

The use of rice husk biomass dryer has implications for the jackfruit Dodol being more hygienic because the drying process is carried out in the drying chamber. The drying process can continue even in cloudy or rainy weather conditions. The use of the rice husk energy dryer for drying the jackfruit Dodol as shown in Figure 1 consists of a) a drying room equipped with a shelf where the jackfruit Dodol is placed, b) a burning stove with a heat exchanger.
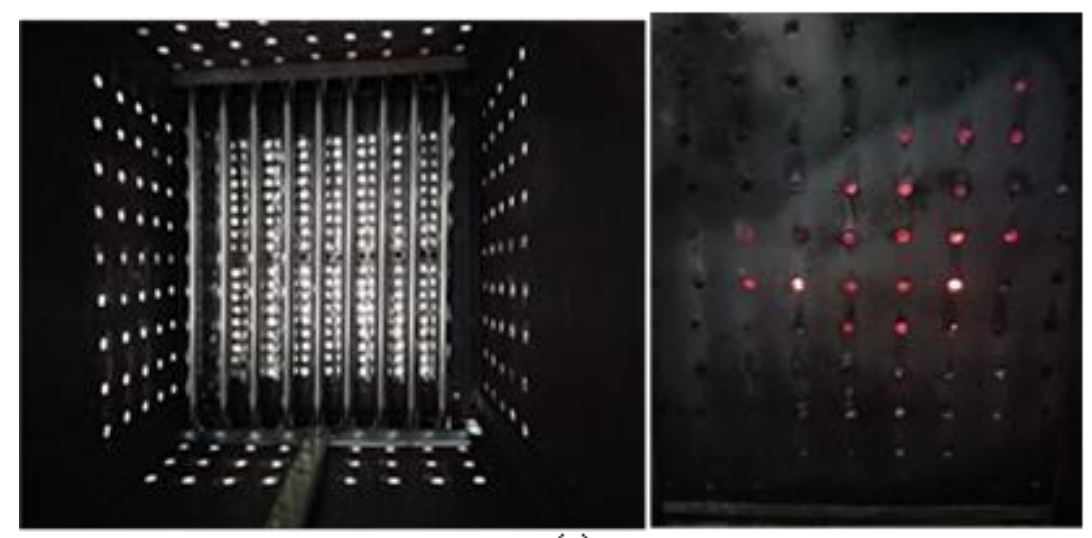

(a)
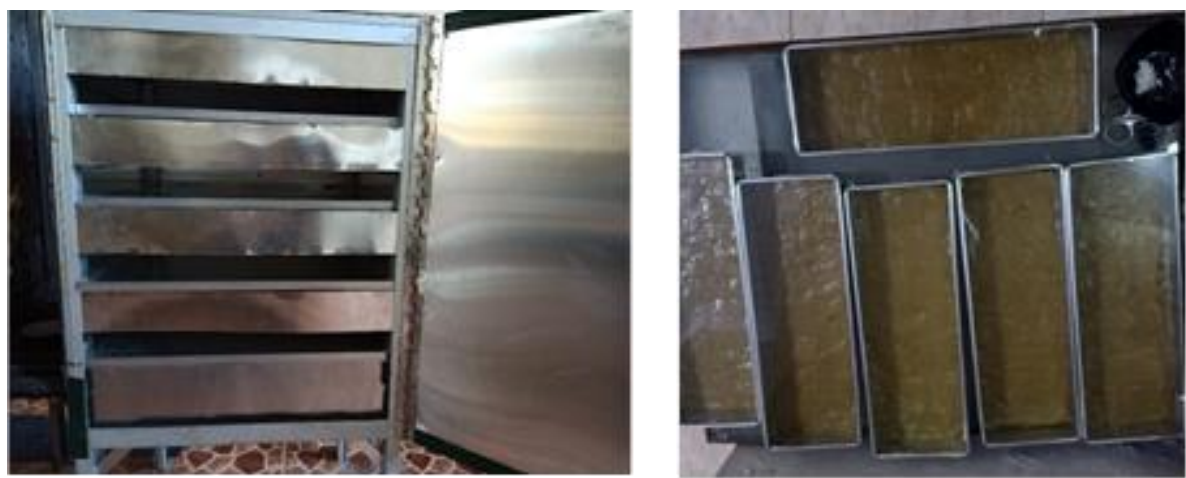

(b

Figure 1 Rice husk energy dryer for drying jackfruit Dodol 


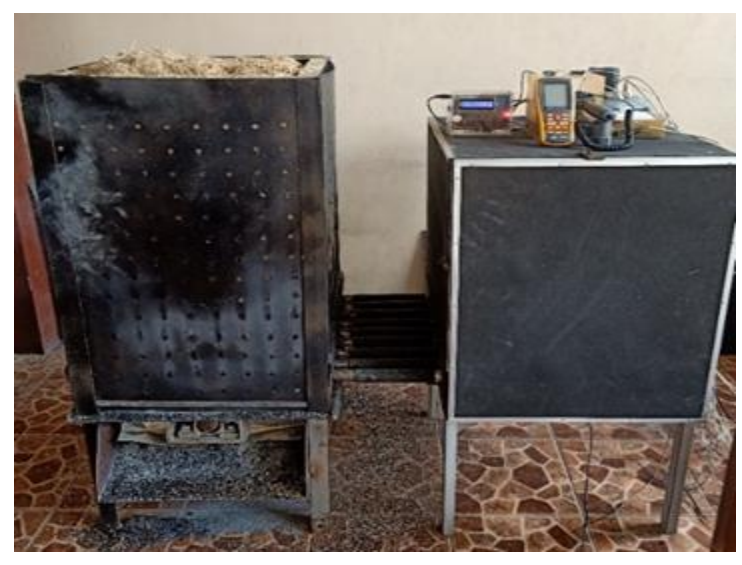

Figure 2 Rice husks for drying energy

Based on the drying temperature, sun drying produces a smaller temperature than using a dryer. The sun drying temperature range is $25.80-29.27^{\circ} \mathrm{C}$. While the drying temperature range using a dryer reaches $37.09-82.47^{\circ} \mathrm{C}$. This results in a shorter drying process for the use of the dryer. Utilization of rice husk biomass as an energy source in the drying process has an impact on the added value of rice waste. The husks are produced from the paddy milling process by $20-30 \%$. The high production of rice husks on the island of Lombok has the potential as sustainable energy for drying food in increasing the standard of life for jackfruit Dodol artisan.

The investment for the drying process of the jackfruit Dodol consists of a dryer of 5,000,000 IDR. To convert the raw material into Dodol, stirring is required. Conventional mixer equipment 2,500,000 IDR. The total investment is 7,500,000 IDR. The investment age of the rice husk energy dryer (n) is assumed to be 7 years. These assumptions are based on general measures to determine the age of the investment. The general measure for determining the age of investment is the same as the time period which is approximately equal to the economic life of the project [17]. The raw materials for one production required in the process of making jackfruit Dodol include $6 \mathrm{~kg}$ of jackfruit at a price of 90,000 IDR; 2 $\mathrm{kg}$ of sugar at a price of 30,000 IDR; rice husk 20,000 IDR. The total raw material for one production is 140,000 IDR. In one month with 15 working days required raw materials of 2,100,000 IDR.

The results of the analysis of the level of benefit (benefit) based on the weight of Dodol produced in each production is $5 \mathrm{~kg}$. Drying with a rice husk energy dryer takes 2 days. The production of jackfruit lunkhead in one month is 15 times. This profit is based on the selling price of Dodol per $\mathrm{kg}$, which is 130,000 IDR, so the profit in one production is $(5 \mathrm{x}$ $130,000$ IDR $)$ - ( $3 \times 75,000$ IDR $)-275,000$ IDR = 150,000 IDR. The amount of 75,000 IDR is the worker's wages for one stirring and two days of drying. Meanwhile, 275,000 IDR is for raw materials and other necessities. The profit in one month (15 working days) is 2,250,000 IDR. In a year the profit reaches $12 \times 2,250,000$ IDR $=27,000,000$ IDR.

The calculation of the payback period (PBP) uses $\mathrm{k}_{(\mathrm{PBP})}$ based on Equation 1. Payback period is 7,500,000 IDR : 27,000,000 IDR $=0.278$ years. Based on the analysis, it is found that the investment cost payback period is 0.2778 years or 3.3336 months. This means $\mathrm{k}<\mathrm{n}(0.2778$ years $<7$ years $)$, so it can be stated that the investment in rice husk energy dryer for drying jackfruit Dodol is feasible.

Analysis of when the jackfruit Dodol artisan did not experience a loss and did not gain a profit using the break-even point (BEP). The calculation is based on the following data.

The total income from the sale of all products produced for 3.3336 months (according to PBP time) is 130,000 IDR/kg x $5 \mathrm{~kg} / 2$ days x 7 days $/ 1$ week x 4 weeks/1 month x 3.3336 months = 30,335,760 IDR.

$\mathrm{p}$ is the selling price of the product unit, in this case based on the selling price of the jackfruit Dodol product, which is $130,000 \mathrm{IDR} / \mathrm{kg}$.

Production volume $(X)=\frac{30,335,760 \mathrm{IDR}}{130,000 \mathrm{IDR} / \mathrm{kg}}=233.35 \mathrm{~kg}$

The break-even point of Dodol jackfruit production using rice husk energy dryer occurs when the production volume reaches $233.35 \mathrm{~kg}$. 
Return on investment (ROI) shows the return on investment that may be obtained within a certain period of time as a result of improving work tools. A certain period of time is the payback period for investment costs. Total sales are 130,000 IDR $/ \mathrm{kg} \times 5 \mathrm{~kg} / 2$ days x 7 days $/ 1$ week x 4 weeks $/ 1$ month x 3.3336 months = 30,335,760 IDR with an investment of 7,500,000 IDR.

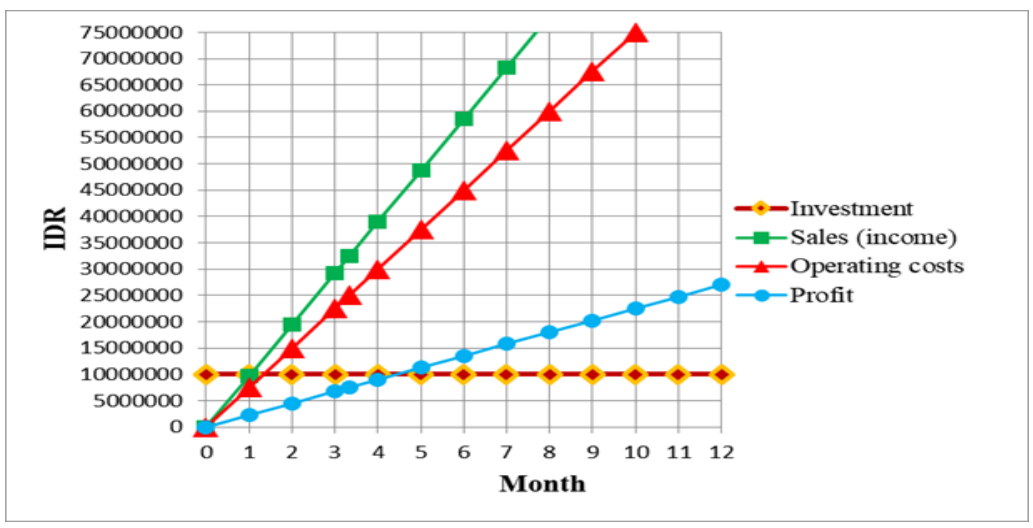

Figure 3 The relationship between investment and profit in the drying process of jackfruit Dodol

The use of rice husk energy dryer provides an ROI rate calculated based on Equation (5) of 304.48\%. The relationship between the investment in rice husk energy dryer and the profits to be obtained by jackfruit Dodol artisan is presented in Figure 3. The application of the rice husk energy dryer in the jackfruit Dodol business give positive results in the form of increased worker income. This is in accordance with research [18] that the drying process through the conversion of biomass energy can increase work productivity by $54.88 \%$ compared to sun drying. In addition, the rice husk energy dryer is feasible in terms of investment to be applied in a household scale industry.

\section{Conclusion}

The application for rice husks energy dryer can increase the income of jackfruit Dodol artisan on a household scale. The profit from the investment in rice husk energy dryer is obtained after 3.3336 months. The application of this dryer in the home industry of making jackfruit Dodol provides an ROI rate of 304.48\%. It can be said that the application of the rice husk energy dryer in the home industry of jackfruit Dodol produces positive results in the form of economic benefits and increased work comfort.

\section{Compliance with ethical standards}

\section{Acknowledgments}

The author also wishes to thank the Department of Mechanical Engineering, University of Mataram for facilitating the implementation of this research.

\section{Disclosure of conflict of interest}

The authors declare no conflict of interest.

\section{References}

[1] RUED Provinsi Nusa Tenggara Barat. Potensi Limbah Perkebunan untuk Biomassa. Peraturan Daerah Provinsi Nusa Tenggara Barat. 2019.

[2] KPMG. Lombok: Prefeasibility Studies on RE Solutions. January 2019.

[3] Burhenne L, Messmer J, Aicher T, Laborie MP. The effect of the biomass components lignin, cellulose and hemicellulose on TGA and fixed bed pyrolysis. Journal of Analytical and Applied Pyrolysis. 2013; 101: $177-184$.

[4] Singh B. Rice husk ash. Waste and Supplementary Cementitious Materials in Concrete. 2018; 417-460.

[5] Awulu JO, Omale PA, Ameh JA. Comparative analysis of calorific values of selected agricultural wastes. Nigerian Journal of Technology. 2018; 37(4): 1141-1146. 
[6] Buchori L, Djaeni M, Kurniasari L. Upaya peningkatan mutu dan efisiensi proses pengeringan jagung dengan mixed-adsorption dryer. Reaktor. 2013; 14(3): 193-198.

[7] Chokphoemphun S, Eiamsa-ard S, Promvonge P. Rice husk combustion characteristics in a rectangular fluidizedbed combustor with triple pairs of chevron-shaped discrete ribbed walls. Case Studies in Thermal Engineering. 2019; 14: 1-7.

[8] Susana IGB, Yudhyadi IGNK, Alit IB, Mirmanto, Okariawan IDK. Effect of hole spacing and number of pipe on dryer box temperature. International Journal of Mechanical Engineering and Technology. 2017; 8(11): 1029-1035.

[9] Susana IGB, Mara IM, Okariawan IDK, Alit IB, Aryadi IGAKCAW. Ash hole variation in rice husk biomass furnace with parallel flow heat exchanger to drying box temperature. ARPN Journal of Engineering and Applied Sciences. 2019; 14(2): 583-586.

[10] Tangka JK, Ngah JK, Tidze VC, Sako ET. A rice husk fired biomass stove for cooking, water and space heating. International Journal of Trend in Research and Development. 2018; 5(6): 83-89.

[11] Incropera FP, DeWitt DP, Bergman T, Lavine A. Fundamental of Heat and Mass Transfer. 6th ed. New York: John Wiley \& Sons. 2006.

[12] Susana IGB. Rancangan ruang pengering berbasis ergonomi menurunkan keluhan muskuloskeletal perajin ikan. Dinamika Teknik Mesin. 2016; 6(1): 15-21.

[13] Mofijur M, Mahlia TMI, Logeswaran J, Anwar M, Silitonga AS, Ashrafur Rahman, SM, Shamsuddin, AH. Potential of rice industry biomass as a renewable energy source. Energies. 2019; 12(21): 1-21.

[14] Purnomo H. Pengantar Teknik Industri. Yogyakarta: Graha Ilmu. 2004.

[15] Giatman M. Ekonomi Teknik. Jakarta: PT. Rajagrafindo Persada. 2007.

[16] Pujawan IN. Ekonomi Teknik. 2th ed. Jakarta: PT. Guna Widya. 2009.

[17] Purbono K, Ainuri M, Suryandono. Rancang bangun dan uji kelayakan finansial alat pengering mekanis untuk pemenuhan pasokan eceng gondok (eichhornia crassipes) sebagai bahan baku kerajinan. Agritech. 2010; 30(2): 80-89.

[18] Susana IGB, Santosa IG. Peningkatan produktivitas perajin ikan teri dengan konversi energi biomassa. Jurnal Logic. 2015; 15(1): 47-50. 